\title{
Breed se verstaan van ' $n$ bybelse pastorale model: 'n Verkennende, beskrywende perspektief
}

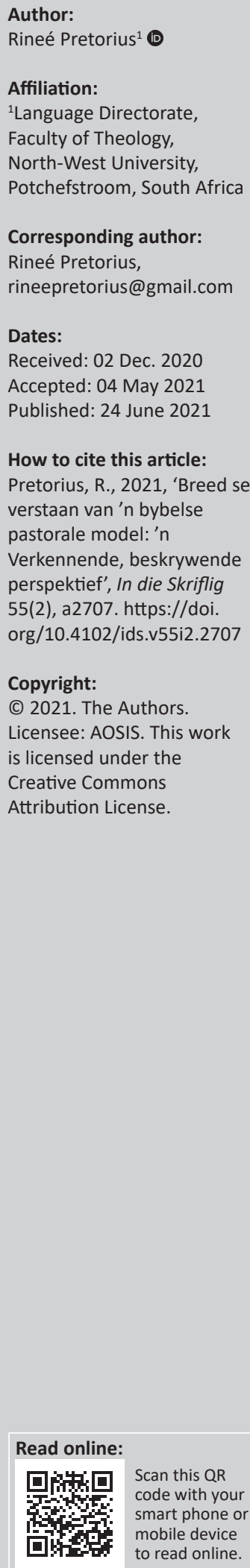

\begin{abstract}
Breed's understanding of a biblical pastoral model: An exploratory, descriptive perspective. This article was aimed at providing a perspective on Professor Gert Breed's theoretical contribution to pastoral studies by exploring and describing his understanding of a biblical pastoral model. Breed's model is the product of decades of research, practical experience as a minister in the Reformed Churches in South Africa and over a decade of theoretical knowledge and experience in training and tertiary academic education. Breed's model currently forms the foundation of and framework for Reformed Churches in South Africa (RCSA) (Gereformeerde Kerke in Suid-Afrika [GKSA]) candidate students' training in pastoral studies at the Theological School in Potchefstroom, as well as for equipping other prospective practitioners for pastoral ministry. Although Breed has been using this model with great success in his own ministry, as well as in tertiary training, a comprehensive perspective on his model had not yet been published.
\end{abstract}

Contribution: The aim of this article was therefore to provide an explorative and descriptive perspective on the content of Breed's understanding of a biblical pastoral model.

Keywords: biblical pastoral model; Coram Deo; Gert Breed; pastoral care; pastoral practitioner.

\section{Inleiding}

Die bydrae van Gert Breed, professor aan die Fakulteit Teologie van die Noord-Wes Universiteit en rektor van die Teologiese Skool Potchefstroom (TSP) tot einde 2020 tot die pastoraat deur sy verstaan van ' $n$ bybelse pastorale model vloei voort uit Breed se praktiese en akademiese kennis sowel as sy ervaring wat oor dekades in die bediening en meer as 'n dekade in tersiêre opleiding opgedoen is.

Aangesien hierdie artikel deel vorm van 'n huldigingsbundel vir Breed, is dit daarop gemik om 'n perspektief te bied op professor Gert Breed se bydrae tot pastoraat. Dit sal gedoen word deur sy verstaan van ' $n$ bybelse pastorale model (voortaan genoem Breed se model) te verken en te beskryf, soos dit neerslag vind in die module PAST122 (voorheen PAST121). Breed se model vorm tans die grondslag van en raamwerk vir GKSA-kandidaatstudente se opleiding in die pastoraat aan die TSP. Dit word ook gebruik vir die toerusting van ander aspirant pastorale praktisyns.

Die verkennende, beskrywende perspektief wat in hierdie studie gebied word, is hoofsaaklik gegrond op my waarnemings tydens prof Gert Breed se interaksie met eerstejaarstudente in die konteks van onderrig en leer, asook die bestudering van voorgeskrewe materiaal en my eie klasaantekeninge tydens simultane tolking van die module en ook soos gebruik in my doktorale studie (Pretorius 2017:191-211).

Breed se werk sluit beginsels deur skrywers soos Larry Crabb, Richard Osmer, Tim LaHaye, John MacArthur, Craig Groome, William Backus en Paul Tripp in. Die fokus van hierdie artikel is op die uiteindelike uitdrukking van Breed se verstaan van 'n bybelse pastorale model, alhoewel daar ook erkenning gegee word aan die elemente, beginsels en invloed van bogenoemde en ander skrywers op die vorming van Breed se verstaan van 'n bybelse model.

\section{Vertrekpunte van Breed se verstaan van 'n bybelse pastorale model}

\section{Verhouding tussen teologie en psigologie}

Volgens Breed (2016:2; 2019a:2) bestaan pastorale sorg uit twee dimensies of lyne: die horisontale lyn (tussen mens en mens) en die vertikale lyn (tussen God en mens), met die klem op die mens as 


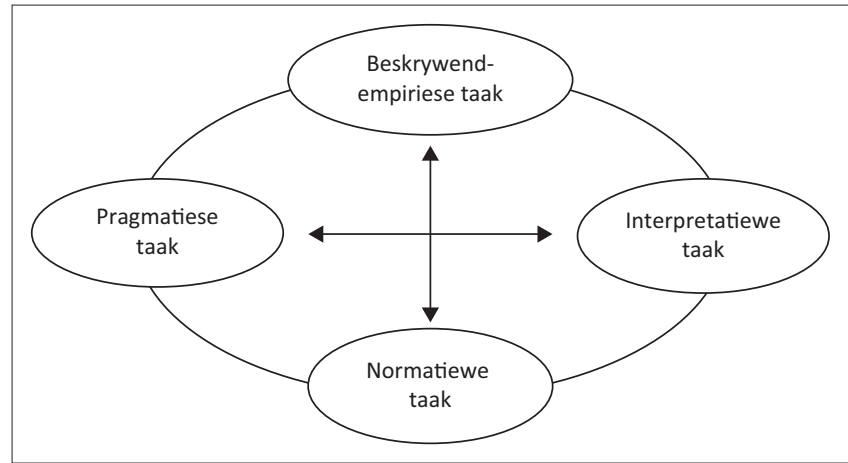

Bron: Aangepas vanaf Osmer, R.R., 2008, Practical theology: An introduction, p. 11, Wm. B. Eerdmans Publishing, Grand Rapids, MI.

FIGUUR 1: Osmer se model.

'n geïntegreerde wese binne 'n sosiale konteks. Psigologie is gebaseer op beginsels aangaande die betekenis van die lewe, self-aanvaarding en optimale selfverwesenliking. Die fokus is op die behoeftes en emosies van die individu, en beoog om individue te begelei om vreugde in hulleself te vind en op onafhanklike wyse antwoorde en oplossings te kry. Omdat die pastoraat geskoei is op die beginsel dat God die Skepper is van alle dinge en Homself in die natuur openbaar, kan die pastoraat met vrug gebruik maak van insigte wat in psigologie ontdek is. Die model van prakties teologiese interpretasie vir Praktiese Teologie, ontwerp deur Richard Osmer (2008:11), toon die plek van naasliggende wetenskappe soos psigologie aan as veral van toepassing tydens die interpretatiewe taak waar die vraag 'Waarom gebeur dit?' aan die orde kom. Pastorale sorg bied egter ook die wil van God vir die mens as die norm aan: 'Wat behoort te gebeur?' (sien die normatiewe taak in Osmer se diagram - Figuur 1) (Breed 2019a:1).

'n Oorbeklemtoning van kennis, emosies of optrede van pastorante op die horisontale dimensie of oorbeklemtoning van die vertikale dimensie, kan 'n negatiewe invloed hê op die pastoraat. Osmer se model kan help om balans in pastorale sorg te handhaaf (Breed 2019a:2).

\section{Die doelwit van die pastoraat}

Crabb (1978:29) verduidelik dat die doel van pastorale berading is: '... om Christelike volwassenheid te bevorder, ten einde mense te help om 'n ryker ervaring van aanbidding en 'n meer effektiewe lewe van diensbaarheid te bereik'. Breed (2013b:6; 2016:3) is dit eens en voeg by dat pastorale sorg verder ten doel het om gelowiges, deur die kragtige werk van die Heilige Gees, tot 'n dieper kennis van God en hulleself te begelei sodat hulle kan groei in geloof. Geloofsvolwassenheid stel gelowiges in staat om lewenskrisisse met vrede te hanteer en om 'n lewe te lei wat God eer.

Pastorale berading wil mense in ' $\mathrm{n}$ nouer verhouding met hulle Skepper bring en lei tot gesprek met God. Mense is wesens in gesprek: gesprek met God, met hulle medemens en ook met hulleself.

Spanningsvolle of traumatiese lewensgebeurtenisse veroorsaak 'n gesprek tussen die mens en die spesifieke situasie (Breed 2013b:2; 2019a:4). Tydens die pastorale gesprek tree die pastorale praktisyn ${ }^{1}$ toe tot die pastorant se gesprek en doen moeite om werklik 'in die verhaal' van die pastorant in te kom.

Die beskrywend-empiriese taak van Osmer se vraag: Wat gebeur/gaan aan?' is hier relevant. Wat vertel pastorante hulleself? Hoe interpreteer hulle dit wat met hulle gebeur?

Pastorante word begelei via die pastorale proses wat die ideale omgewing skep om leiding, goeie praktiese advies, troos en toerusting te ontvang in terme van die uitdagings wat die lewensituasie meebring. In wese is die oogmerk dat die pastorale praktisyn bloot as fasiliteerder in die gesprek tussen God en mens optree (Breed 2016:4; 2019a:4). 'n Traumatiese ervaring veroorsaak 'n gesprek in die mens se gedagtes; nie net 'n gesprek met God nie, maar ook'n gesprek met die situasie, met die persoon self en ook ander mense. Die pastorale praktisyn tree tot hierdie gesprekke toe ten einde ' $n$ beter begrip en insig te bekom van hierdie gesprekke wat reeds besig is om plaas te vind. Die toetrede is beperk en die pastorale praktisyn tree uit die gesprek tussen die pastorant en God sodat die pastorant onafhanklik kan voortgaan.

Pastorale praktisyns kan gelowiges nie na 'n gesprek met God lei indien hulle nie die wedersydse gesprek tussen God en mens ten volle verstaan nie. Die basiese beginsels wat onderliggend aan Breed se model is, bied insigte in verband met hierdie gesprek.

\section{Rol van die pastorale praktisyn}

Omdat die pastorale praktisyn geroep is om in diens van Christus te staan en in 'n lewende verhouding met Christus leef, straal die pastorale praktisyn die gesindheid van Christus uit. Hierdie gesindheid impliseer ' $n$ totale uitstorting van 'n mens se lewe om ander te dien en vorm die grondslag waarop die pastorale verhouding gebou sal word (Breed 2019a:3).

Voor elke ontmoeting bid die pastorale praktisyn om wysheid en insig sowel as vir die Heilige Gees om die pastorant te vertroos en vrede te gee. Op hierdie manier herinner pastorale praktisyns hulleself daaraan dat dit die Heilige Gees is wat in die lewens en harte van pastorante werk.

Met die oog hierop kan die pastorale praktisyn daarop fokus om 'n vertrouensomgewing te skep waarbinne pastorante ervaar dat daar werklik na hulle geluister en vir hulle omgegee word. Die fokus om toegang tot die pastorant se verhaal te verkry, behels veel meer as om bloot die normatiewe wil van God voor te hou; meer spesifiek gaan dit daaroor om hulle in gesprek met God Drie-enig te bring ten einde deur hierdie verhouding getroos, aangemoedig en onderrig te word. Dit is 'n poging om te verstaan en te bepaal wat die genade van God die Vader, die Seun en die Heilige Gees in hierdie spesifieke konteks beteken en om God se Woord in hierdie situasie in te bring en die genade van die Here te verkondig (Breed 2016:4; 2019a:4).

1.Die term pastorale praktisyn word gebruik as kollektiewe term wat pastorale werkers, beraders, predikante en pastors insluit. 


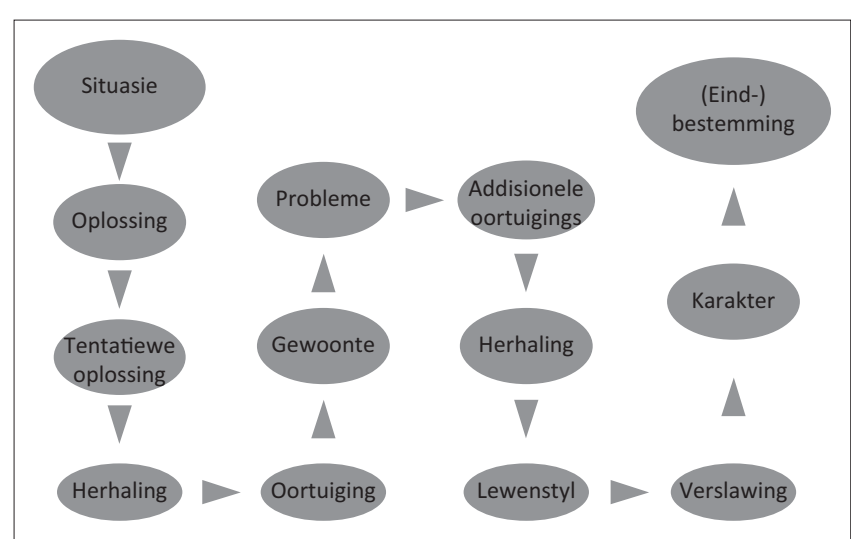

Bron: Aangepas vanaf Breed, G., 2016, 'n Bybelse pastorale model, lesings 1-12, Verkry uit PAST121 NWU, Potchefstroom. (Ongepubliseer); en Pretorius, R., 2017, 'Pastoral care and counselling of families with deaf children: A practical theological model', p. 195, PhD thesis, North-West University, Potchefstroom.

FIGUUR 2: Samevatting van die verband tussen verandering en die mens se gedagtes en oortuigings.

\section{Die basiese fondasie aan die grondslag van Breed se bybelse model}

Die verhouding tussen die mens se denke, emosies en dade sowel as die noue samehang daarvan met verandering soos in die pastoraat teweeggebring, is grondliggend tot Breed se model. Figuur 2 is 'n samevatting van die vloei van die gesprek in die mens se gedagtes (Breed 2013b:4; 2019a:5).

\section{Die mens as 'n wese in gesprek}

Reformatoriese navorsing gaan uit van die bybelse beskouing van die mens: dat die mens as beeld van God en as sy verteenwoordiger geskape is, wat kommunikasie tussen God en mens veronderstel (Breed 2013b:2). Mense praat voortdurend in hulle gedagtes met God, hulleself, hulle oortuigings en omgewing om sin te probeer makk van die lewe, lewensgebeurtenisse en om 'n manier te vind om pyn te verminder en oplossings te vind vir lewensprobleme. Hierdie gesprek in die mens se gedagtes bepaal die mens se reaksie in lewensituasies.

\section{Verandering is nou verwant aan die mens se gedagtes, oortuigings en gedrag}

'n Traumatiese lewensgebeurtenis of -situasie kan tot 'n krisissituasie lei waarin die gelowige voor besluite te staan kom in terme van hoe om te reageer op die spesifieke situasie. Hierdie besluite wat 'n persoon neem, kan 'n oortuiging word indien dit in soortgelyke situasies herhaaldelik toegepas en bevestig word.

Oortuigings verander nie maklik nie en is nie noodwendig op waarhede en werklikhede gebaseer nie, maar spruit dikwels voort uit 'n verkeerde begrip en leuens. Die gevolge van besluite, optrede of gevoelens wat op hierdie oortuigings gebaseer is, kan op hulle beurt probleme skep en persone se karakter bepaal, wat uiteindelik weer hulle bestemming bepaal. Mens se lewens word dus sterk beïnvloed deur hulle besluite en oortuigings (gebaseer op waarhede en/of onwaarhede).

Hierdie oortuigings word deur herhaling (wat tot 'n gewoonte lei) of trauma (lewensgebeurtenisse wat 'n groot invloed op 'n mens se lewe het) gevorm en wanneer dit eenmaal vasgelê is, is dit moeilik om te verander (Breed 2019a:5).

Gelowiges klop by pastorale praktisyns aan met die gevolge van die proses, probleem of problematiese gedrag as resultaat van problematiese emosies, veroorsaak deur problematiese oortuigings (leuens). Op die lang termyn is die hantering van alleenlik die problematiese gedrag oneffektief. Ten einde permanent effektiewe gedragsverandering te bewerkstellig, is dit belangrik dat eerder op die oorsprong of wortel (gewoonlik oortuigings) van problematiese gedrag gefokus en dít hanteer word (Breed 2016:5, 2019a:5).

\section{Die beginsels van Breed se verstaan van 'n bybelse pastorale model}

- God het die mens geskep om in verhouding met Hom, sy of haar medemens en die skepping te leef: Verhoudings is egter verwring en vernietig as gevolg van die sondeval. Waar die verhouding tussen mens en God bedoel was om intiem te wees en die mens die nabyheid, voorsienigheid en liefde van God moes ervaar, probeer mense nou vir hulleself sorg en ervaar hulle vrees en leegheid, aangesien hulle God nie kan liefhê en gehoorsaam soos wat dit bedoel was nie en dit laat 'n diep leemte (Breed 2016:4). Die verhouding tussen mens en medemens is veronderstel om deur vertroue, eerlikheid en nabyheid waarin mense mekaar dien en opbou, gekenmerk te word. Na die sondeval wantrou en misbruik mense mekaar wat verhoudings vol pyn en bitterheid tot gevolg het. Die mens is verder geskep om die skepping te bewerk en te bewaar, en die skepping sou met vrug antwoord sodat die mense die resultaat van hulle werk kon ontvang en daarby baat. Tog reageer die skepping nie soos dit bedoel was nie en bring dit dorings en dissels voort wat die mens verslae, teleurgesteld en akuut leeg laat (Breed 2016:4; 2019a:4).

- Pogings om die pyn te genees en die innerlike leemte te vul: Wanneer mense leegheid, pyn of frustrasie ervaar, wil hulle die pyn genees, vermy of wegkom daarvan en poog hulle (bewustelik en onbewustelik) om hierdie leemte te vul. As 'n poging suksesvol blyk te wees, gebruik hulle dit herhaaldelik om die pyn te verdoof. Soos hierbo gesien, veroorsaak hierdie herhaling van gedrag later gewoontes wat weer oortuigings (gebaseer op leuens en/ of waarhede) in die mens se onderbewussyn tot gevolg het. Oortuigings gebaseer op leuens bied slegs tydelike oplossing vir probleme en kan meer probleme veroorsaak en die mens in die proses verslaaf (Breed 2019a:5). Breed verduidelik hierdie tydelike aard van oplossings gebaseer op leuens deur na Jeremia 2:13 te verwys:

... want my volk het twee verkeerde dinge gedoen: My, die fontein van lewende water, het hulle verlaat om vir hulle reënbakke uit te kap, gebarste reënbakke wat geen water hou nie ...

God is die fontein van lewende water. Hy is altyd teenwoordig in die lewe van die gelowige en dus kan Hy ter enige tyd genader word om genade te ontvang. Indien 
daar egter op verkeerde plekke na oplossings gesoek word om hierdie leemte te vul, sou dit vergelykbaar wees met ' $n$ poging om water te probeer opvang in 'n gebarste bak wat uit die aard van die saak nie water kan hou nie (Breed 2016:5; 2019a:5).

- 'Godvormige' leegheid: Die gevolgtrekking waartoe Breed kom in terme van die leegheid wat die mens as gevolg van die sondeval ervaar, is dat oplossings, gebaseer op valse oortuigings, wel kortstondige verligting kan bring, maar dat dit die mens onvervuld laat en verhoed om 'n lewe in oorvloed te geniet. Hierdie leemte is 'Godvormig' wat beteken dat niks of niemand anders as juis God Drie-enig blywende verligting kan bring en hierdie leemte kan vul nie (Breed 2016:4):

'Kom, almal wat dors is, kom na die water toe, selfs ook dié wat nie geld het nie, kom, koop en eet; ja, kom, koop sonder geld en sonder om te betaal, wyn en melk' (Jes $55: 1)$.

- Gewoontevorming: Gevestigde oortuigings in die hart van die mens word aangewend om in spesifieke situasies te reageer. Breed (2019a:5) verduidelik dat die mens oor die Godgegewe vermoë beskik om gewoontes te vorm (gewoontekapasiteit). Gewoontekapasiteit stel die mens in staat om herhaalde oplossings (oortuigings) te stoor om later te herroep as semi-outomatiese reaksies wat nie meer aktiewe besluitneming vereis nie. Hierdie oplossings word dus in die brein vasgelê en bepaal gedrag. Breed onderskei tussen die oortuigings wat in die brein gestoor is, bestaande uit leuens, ongeïntegreerde waarhede, gedeeltelik geïntegreerde waarhede en geïntegreerde waarhede. Klem word op die belangrikheid daarvan gelê om problematiese oortuigings te identifiseer en met waarhede te vervang, en om ongeïntegreerde en gedeeltelik geïntegreerde waarhede te ontwikkel om as ten volle geïntegreerde waarhede in die gelowige se lewe te funksioneer. Bogenoemde word nie bereik deur blote wysiging van gedrag (verbreking van die gewoonte) nie, maar om eerstens oortuig te wees van die waarheid en om dan herhaaldelik en bewustelik hierdie verbintenis tot die nuwe waarheid te maak totdat 'n nuwe gewoonte gevorm word (Breed 2016:5, 2019a:5).

\section{Teoretiese raamwerk vir die pastoraat: Drie ankerpunte}

Pastorale praktisyns behoort oor'n sterk teoretiese raamwerk te beskik vanwaar pastorale sorg of berading aan gelowiges op teologies verantwoordbare wyse gebied kan word. Pastorale praktisyns bejeën pastorante vanuit die perspektief dat hulle deur God, na sy beeld en vir 'n spesifieke doel geskep is.

Soos kortliks vroeër uiteengesit, beleef die mens 'n diepe leegheid na die sondeval (wat die mens probeer vul; 'n dors wat die mens op verskillende tydelike maniere probeer les) wat slegs deur God Drie-enig gevul en geles kan word met sy lewende water. Gelowiges behoort dus pastoraal begelei te word om God te ken en te begryp. Dit weerspieël die omvang van genade wat toenemend meer word (lewende water - Joh 4:10-14). Slegs wanneer gelowiges begelei word om hierdie lewende water (genade) van God te aanvaar, kan werklike vervulling, vrede en vreugde in hulle lewens ervaar word (Breed 2016:5). Die drie Persone van die Drie-eenheid vorm die drie teologiese ankerpunte wat die lewe van die gelowige, en daarom ook die bybelse pastorale model, omraam.

\section{Eerste ankerpunt: Die liefde van God die Vader en sy doel met ons lewens}

Die rol van die pastorale praktisyn behoort, volgens Breed (2019a:6), verstaan te word binne die konteks van God se plan met en in verhouding tot hierdie realiteit. Daarom behoort uit die staanspoor gevra te word na God se doel en wil vir pastorante in hulle situasie.

In terme van basiese emosionele behoeftes van die mens, beklemtoon Breed (2019a:6) veiligheid en onvoorwaardelike en onverdiende liefde as die menslike behoeftes wat, indien dit bevredig word, angs en verdedigende gedrag verminder. Kennis van die Vader se genade en onverdiende liefde is noodsaaklik om 'n lewe van oorwinning te lei juis omdat onvervulde verlange vanuit ' $n$ tekort aan kennis van God en sy liefde spruit, en omdat daar nie ten volle vanuit sy genade geleef word nie.

Om gelowiges te lei tot 'n opregte belydenis dat God hulle herder en veilige vesting is en dat hulle werklik niks anders nodig het nie, is dus 'n belangrike doelwit van die pastoraat (Breed 2019a:6). Breed (2019a:6; 2019b:13) verduidelik die waarde van Psalm $23^{2}$ ten einde gelowiges tot dieselfde belydenis as Dawid in Psalm 23:1 te lei: 'Die Here is my herder; Ek kom niks kort nie.' Verder ook om te kan bely: God is by my. Ek het alles wat ek nodig het, ongeag wat in hierdie lewe gebeur. 'Met sy stok en sy staf vertroos Hy my': Om te ervaar dat, selfs al beleef gelowiges teenspoed, die Here werklik omgee en hulle beskerm soos 'n herder sy skape. Hulle is eregaste by sy feesmaal, kinders in sy huis en hulle bekers loop oor. Te midde van swaarkry, lyk die piek van die spreekwoordelike berg aanvanklik onbereikbaar. Tog is dit werklik moontlik om, ten spyte van herhaalde kere van val en opstaan, uit die donker dieptes terug te keer en die bergpiek te bereik. Pastorante sal dan in staat wees om te bely dat die Here hulle herder is, Hy by hulle is en hulle Hom vertrou, ongeag hulle lewensomstandighede.

\section{Tweede ankerpunt: Troos van die versoenende werk van die Seun, Jesus Christus}

Om met hulle eie bagasie en gebrokenheid gekonfronteer te word, kan gelowiges moedeloos en skaam laat. Die mens se identiteit lê egter nie in die gebrokenheid nie, maar eerder in die versoening wat deur Christus bewerkstelling is en, voortvloeiend hieruit, om Christus te dien. Christus se versoening tussen God en mens het die verhouding tussen die mens en sy Vader herstel. Breed (2016:6; 2019a:6) gebruik

2.In die lig van die beperking op die lengte van die artikel word verdere toeligting oo die gebruik en toepassing van voorgestelde teksgedeeltes oor al drie ankerpunte die gebruik en toepassing van voorgestelde teksgedeeltes oor al drie ankerpunte
(bv. Ps 23; Ef 6 en Fil 2) in die pastorale proses in hieropvolgende artikels breedvoerig hanteer. 
Efesiërs 6 om gelowiges se konfrontasie met vyandige magte te beskryf en te illustreer hoe God Drie-enig gelowiges krag gee deur hulle kennis van Hom, sodat hulle hul roeping volgens sy raadsplan kan uitvoer.

Verder word Filippense 2:1-5 gebruik om aan te dui wat die vertroosting of aanmoediging behels wat gevind word in die versoenende werk van Christus ten einde die besef tot pastorante te laat deurdring dat hulle werklik aanvaarbaar is en hierdie aanvaarding deur die Vader kan beleef. Dit herinner pastorante daaraan dat hulle ' $n$ bepaalde doel het in hierdie lewe en hulle word dus begelei om sterkte in God se krag te vind.

\section{Derde ankerpunt: Die Heilige Gees en ons heiligmaking}

Die pastorale praktisyn kan dalk nie die volle omvang van pastorante se unieke situasie goed genoeg begryp om in staat te wees om hulle te troos nie, maar uiteindelik is dit die Heilige Gees wat troos. Hy woon in hulle en is by hulle in hul situasie. Tye wanneer pastorale praktisyns moontlik onbevoeg voel in hulle begeleiding aan pastorante, kan hulle vertrou dat die Heilige Gees, as die Parakleet, ook hierdie begeleiding steeds kan gebruik om met pastorante te werk en hulle te vertroos. Die werk van die Heilige Gees is onlosmaaklik deel van die werk van Christus; daarom hoor die pastorante deurentyd die stem van die Goeie Herder deur die werk van die Heilige Gees (Breed 2019a:8).

\section{Die Heilige Gees as leidsman in waarheid en begrip (insig)}

Die Heilige Gees ken elke vrees, begeerte, behoefte en gedagte van gelowiges. Hy lei gelowiges in die waarheid en bring vrede in gelowiges se harte sodat hulle nie bang hoef te wees nie (Joh 14:26-27). Hy wys gelowiges gedurig op die waarheid en transformeer hulle harte om aan die waarheid te voldoen. Die Gees herinner gelowiges verder aan spesifieke waarhede uit die Skrif wat van toepassing is op hulle spesifieke situasie (MacArthur 1994:136). Uit 1 Korintiërs 2:9-11 kan gelowiges gelei word om te verstaan dat die Gees hulle deur en deur ken. God stuur sy Gees om in ons te woon en om aan sy kinders te verduidelik wie God is, sodat gelowiges Hom werklik kan ken (Breed 2019a:8).

\section{Die Heilige Gees bemagtig om lief te hê (Rom 5:1-5)}

Deur Christus het gelowiges vrede en vrye toegang tot God (Rom 5:1). Die Heilige Gees bemagtig gelowiges om Christus lief te hê en te gehoorsaam (Rom 5:5; Breed 2016:8; MacArthur 1994:139). God gebruik swaarkry en lyding om gelowiges se geloof te versterk (Rom 5:3-4), want dit is in hierdie tye van wanhoop dat gelowiges deur moeilike oortuigings gekonfronteer word en hulle hul geloof moet lééf. In hierdie tye is hulle in gesprek met hulle situasie en bevraagteken moontlik hulle geloof - het Christus werklik vir hulle gesterf; is die Heilige Gees werklik by hulle; sorg God werklik vir hulle soos 'n vader? Hulle word dan begelei om hulle situasie te sien as iets wat God in hulle lewens gebruik. Wanneer gelowiges hierdie proses van volharding en versterking van geloof deurmaak, wek dit uiteindelik hoop omdat God se liefde in hulle harte uitgestort is. Hulle hou vas aan die waarhede met die wete dat volharding karakter en uiteindelik hoop kweek. Vertroue in God word gekweek, want as gelowiges nie hulle geloof verloor wanneer hulle lyding verduur nie, sal hulle vertroue hê in die feit dat God weer by hulle sal wees en hulle sal deurdra indien hulle weer lyding sou ondervind (Breed 2019a:8). Die Heilige Gees werk in die harte van gelowiges en herinner hulle aan die liefde van hulle Vader. Vervolgens word gelowiges in staat gestel om ander lief te hê omdat hulle die liefde van God ken (Breed 2016:8; 2019a:8).

Die wapenrusting van God (Ef 6) word hier gebruik om God Drie-enig se reddingsdade voor te stel wat die mens in staat om vas te staan in die bogenoemde worsteling of geveg.

Pastorante word begelei om te verstaan en te glo wat die troos in Christus in hulle situasie beteken - dat hulle aanvaarbaar is vir die Vader as gevolg van die werk van Christus. Hulle kan verder biddend verwag dat God in hulle werk met dieselfde krag waarmee Hy Christus uit die dood opgewek het. Dus, selfs in 'n hopelose situasie, waar pastorante lyding ervaar, is God daartoe in staat om baie meer te doen as wat hulle verwag volgens die krag in hulle (Ef 3:20).

\section{Die rol van gebed in die pastorale proses}

Gebed vorm 'n onontbeerlike deel van die pastorale proses. Die pastorale praktisyn se rol behels die begeleiding van pastorante om te bid vir die vervulling van die Heilige Gees sodat die vreugde en vrede van God hulle lewens mag vul en dat die Gees hulle die wysheid sal gee om spesifieke situasies te hanteer. Die Gees verwerklik die liefde en die teenwoordigheid van die Vader sowel as die redding en oorwinning van die Seun in die lewens van gelowiges (Breed 2019a:8).

Die doel van die pastorale praktisyn se toetrede tot die gesprek tussen die pastorant en God is om pastorante te begelei om in gesprek, gebaseer op waarhede uit die Skrif, met God te tree en om die genade van die Drie-enige God te aanvaar en dit hulle eie te maak (Breed 2019a:4).

Dit is belangrik dat pastorale praktisyns se eie lewens getuig van 'n intieme verhouding met God ten einde in staat te wees om pastorante te begelei tot 'n soortgelyke verhouding met God. Geesvervulde pastorale praktisyns laat hulle lei deur die Heilige Gees waarsonder deurbrake in die pastorale proses en groei in 'n nuwe lewe onmoontlik sou wees (Breed 2019a:8).

\section{Die plek van die Bybel in die pastorale proses}

Die Skrif speel uit die aard van die saak 'n belangrike rol in elkeen van die fases van die beradingsproses. Pastorante 
word met behulp van die Bybel begelei om die gesprek met hulle situasie, hulleself, met ander en met God op bybelse grondslag te voer, om in die teenwoordigheid van God hulle harte tot Hom op te hef en met Hom te worstel oor hulle situasie, vrae en lyding. Sodoende worstel hulle saam met God daardeur ten einde 'n sin van helderheid en vrede te bereik. Op hierdie manier groei pastorante in die bestudering, kennis en toepassing van die Bybel en kan hulle uiteindelik ook ander op soortgelyke manier begelei (Breed 2019a:10).

\section{Die pastorale proses van Breed se verstaan van 'n bybelse model vir pastorale berading}

Tydens die pastorale proses sluit die pastorale praktisyn aan by 'n reis in die lewe van die pastorant.

Daar is 'n dinamika tussen die pastorale praktisyn en die pastorant. Hulle gesamentlike reis bestaan uit sekere fases en stappe waardeur beweeg word. Alhoewel die proses uit stappe bestaan, word hierdie stappe nie noodwendig een na die ander voltooi nie, maar is dit dikwels eerder in die vorm van 'n spiraal (Breed 2019a:10).

Die fases van Breed se model stem soos volg ooreen met die vier take van Osmer se model vir die toepassing van prakties teologiese interpretasie (sien Figuur 3).

\section{Verhoudingbou en data-insamelingsfase}

Verhoudingbou: Wanneer pastorante by 'n pastorale praktisyn aanklop, worstel hulle waarskynlik reeds 'n geruime tyd met 'n spesifiek probleem en is dit nie maklik om uit die staanspoor die volle spektrum van hulle diepste gevoelens en emosies bloot te lê nie. Die pastorale praktisyn behoort dit in ag te neem en tyd te belê in die opbou van 'n vertrouensverhouding. Elemente van liefde, begrip, vertroue, openheid en aanvaarding is van kardinale belang in die kweek van 'n pastorale vertrouensverhouding. Pastorale praktisyns aanvaar pastorante onvoorwaardelik juis omdat Christus hulle aanvaar het. Daarbenewens plaas pastorale praktisyns hulleself in pastorante se skoene ten einde opregte empatie te kan toon (Breed 2016:9; 2019a:9).

\begin{tabular}{|c|c|}
\hline Die take van Osmer se model & Die fases van Breed se model \\
\hline $\begin{array}{l}\text { Beskrywend empiriese taak van priesterlike } \\
\text { luister om te ontdek 'Wat gebeur/gaan aan?' }\end{array}$ & Verhoudingbou en \\
\hline $\begin{array}{l}\text { Interpretatiewe taak van verstandige wysheid om } \\
\text { te verstaan 'Waarom gebeur dit/gaan dit aan?' }\end{array}$ & en data-insameling \\
\hline $\begin{array}{l}\text { Normatiewe taak van priesterlike } \\
\text { onderskeidingsvermoë om te bepaal 'Wat behoort } \\
\text { te gebeur?' }\end{array}$ & Coram Deo \\
\hline $\begin{array}{l}\text { Pragmatiese taak van dienende leierskap ten einde } \\
\text { die vraag 'Hoe kan ons reageer?' aan te spreek. }\end{array}$ & \\
\hline
\end{tabular}

Bron: Pretorius, R., 2017, 'Pastoral care and counselling of families with deaf children: A practical theological model', p. 204, PhD thesis, North-West University, Potchefstroom. FIGUUR 3: 'n Illustrasie van Osmer se take van prakties teologiese interpretasie en korrelasie daarvan met die eerste fases van Breed se model vir pastorale berading.
Veral tydens die aanvanklike ontmoetings kom pastorale praktisyns tot die besef dat die gesprek in die gedagtes en gemoed van die pastorant nie volkome geken en begryp kan word nie. Effektiewe ondersoekende vrae en kaatsingstegnieke word gebruik om tot 'n beter begrip te kom. Pastorale praktisyns tree tydelik toe tot en word deel van die gesprek wat pastorante reeds met hulleself, hulle situasie en God gevoer het. Deur 'n verhouding met pastorante op te bou, word hierdie gesprek verstaanbaar (Breed 2019a:4).

Nadat tot hierdie verhouding toegetree is, kan pastorale praktisyns die leuens en ongeldige oortuigings waarop pastorante hulle lewens bou, begin ontdek en ondersoek. Hierdie oortuigings lei tot bepaalde emosies wat aanleiding gee tot spesifieke gedrag. Die gedrag lei tot sekere gewoontes wat dan weer tot 'n spesifieke manier van leef en uiteindelik tot ' $n$ bestemming lei. By die ondersoek na die leuens en ongeldige, verkeerde of valse oortuigings het pastorale praktisyns die geleentheid om dit met waarhede uit die Skrif te vervang. Hierdie proses om leuens met waarhede te vervang, bestaan daaruit om elke keer te bevestig dat die pastorant die waarheid glo, en om dit dan te oefen en te herhaal totdat dit 'n nuwe oortuiging, gebaseer op die waarheid, word (Breed 2019a:9). Hierdie fase van verhoudingbou en data-insameling berei die weg voor vir die volgende fase, naamlik dié van Coram Deo.

\section{Die Coram Deo-fase}

Daar word dikwels na die tweede fase van die beradingsproses in die algemeen verwys as die konfronterende fase, aangesien pastorante hier gekonfronteer word met onwaarhede in hulle lewens en tot bekering en inkeer geroep word. Breed (2019a:2) beklemtoon dat, deur daarna te verwys as die konfronterende fase, die vertikale dimensie te veel beklemtoon word en nie genoeg aandag aan die horisontale dimensie gegee word nie. Daarom verkies Breed om na hierdie fase te verwys as die Coram Deo-fase [Latynse uitdrukking: 'n mens leef in die teenwoordigheid van en vertroue in die Here] waar ewe veel klem op albei dimensies geplaas word.

Deur hulle aan die Here se wette van genade bekend te stel, word pastorante nie bloot met die wet gekonfronteer nie, maar ontvang ook die verkondiging van die genade van die Here. Coram Deo gaan hand aan hand met Sursum Corda wat beteken om 'n mens se hart op te hef. Pastorante word begelei om voor God te staan, hulle harte tot God op te hef en hulle lewe in die lig van God se Woord te beskou (Breed 2019a:2).

\section{Coram Deo}

God word pertinent in die gesprek gebring op die volgende wyses:

- Deur die Woord van God: Pastorante word na die Woord van God begelei om hulle eie oortuigings (dikwels gebaseer op leuens) met die waarhede uit die Skrif te vergelyk (Breed 2019b:9). Die leuens word ondersoek om valse oortuigings bloot te lê wat dan deur die waarheid vervang word deur hulleself herhaaldelik tot die 
waarheid te verbind. Pastorante word herinner aan die betekenis van die drie ankerpunte en hoe dit op hulle situasie van toepassing is (Breed 2019a:11).

- Deur die Heilige Gees wat in mense werk deur die Woord: Die Heilige Gees lei hulle en bevestig die Woord aan hulle as die waarheid. Die Heilige Gees kan uiteindelik die valse oortuigings met die waarheid vervang om 'n nuwe gewoonte te vorm. Sodoende word die ou gewoonte gebreek onder leiding van die Heilige Gees (Breed 2019a:8).

- Deur die pastorale proses: Naas die Heilige Gees, kan die pastorale gesprek op sigself as die voorbeeld van die pastorale praktisyn se lewe dien sowel as 'n manier om God in die gesprek te bring.

Wanneer die pastorant sien dat die pastorale praktisyn die Woord van God aanvaar, daarvolgens leef en dat die Woord van God vrede en vreugde vir die pastorale praktisyn bring, kan die Heilige Gees nog kragtiger werk deur die voorbeeld wat die pastorale praktisyn stel (Breed 2016:8):

- Direk: God kan deur die Woord, die Heilige Gees en die pastorale gesprek werk, maar direk deur die Heilige Gees.

Die Coram Deo-fase bestaan uit die bymekaarbring van die wet (gebooie), sowel as die genade van die Here. Die pastorant word begelei om die drie ankerpunte te verstaan, asook te begryp wat die implikasies van die Vader se liefde, die troos in Christus en die gemeenskap met die Heilige Gees in hulle huidige situasie is. Breed (2019a:6) meen dat Johannes 15:8-11 twee kante van die Vader se sorg illustreer. Nie net sorg God vir gelowiges nie, maar Hy gee ook grense (gebooie) waarbinne gelowiges moet leef. Hierdie grense beperk wel, maar word gegee omdat God gelowiges liefhet. Wanneer die pastorant die genade van die Here verstaan, word die wette (gebooie) wette van liefde wat gelowiges help om in die liefde van God te bly.

\section{Gebed as gesprek het God}

Gebed speel 'n fundamentele rol in die pastorant se nadering tot God en die gesprek met Hom wat daaruit voortvloei. Die pastorale praktisyn bid voortdurend vir die pastorante en lei hulle om persoonlik met God in gesprek te tree. Slegs die Heilige Gees kan 'n ware gesprek met God laat plaasvind deur in die gelowige se hart te werk. Die gebruik van gebed kan dalk soms beskou word as byna ' $n$ formele handeling of 'n plig wat nagekom behoort te word. Die pastorale praktisyn weerlê hierdie siening en bring bewustheid van die wonderlike gawe van gebed. In gebed kan die gelowige veiligheid en ' $n$ toevlug vind in die teenwoordigheid (Ps 16) en krag van God se mag (Ef 6:10). Gebed is gemeenskap met God en gelowiges kan vrylik en met vrymoedigheid met God praat en hulle harte voor Hom uitstort. Deur hulleself as lewende en heilige offers te gee, probeer gelowiges die wil van God bepaal in hulle huidige situasie, kan hulle met God worstel oor die dinge wat hulle nie verstaan nie en kom hulle deur die proses in die intieme nabyheid van God.
Gebed neem dus ' $n$ belangrike plek in omdat pastorante met opregtheid hulle gevoelens teenoor God kan uitdruk. Hulle praat met God oor die innerlike gesprek wat hulle vroeër met hulle omstandighede of situasie gevoer het, die nuwe waarhede wat hulle ontdek het en vra God in afhanklikheid om hulle te help om hulleself te verbind tot die nuutontdekte insigte.

\section{'Verantwoordbaarheidsvennote'}

Die rol van 'n verantwoordbaarheidsvennoot ${ }^{3}$ (veral in gevalle van verslawing) speel 'n belangrike rol in die proses van die vervanging van leuens met waarhede en verbintenis tot hierdie waarhede. Pastorante moet na hierdie persoon of persone kan draai wanneer hulle begin twyfel of dalk weer teruggeval het in vorige maniere van dink en doen of onderskraging benodig. Die rol van die verantwoordbaarheidsvennoot is om pastorante telkens aan die genade en gebooie van God te herinner. Sodoende word pastorante gehelp om elke keer vinniger as voorheen op te staan na hulle geval het en word ook voorkom dat hulle nie in die toekoms so diep val soos voorheen nie (Breed 2019a:10).

\section{Fase drie: Gehoorsaamheid en volharding}

Die derde fase van Breed se model is daarop gerig om pastorante te help om die gewoonte om volgens die vals oortuigings te leef, prakties te verbreek, die waarhede in hulle lewens te integreer en om te volhard in die besluite wat hulle geneem het om uiteindelik nuwe gewoontes wat op waarhede gebaseer is te vorm (Breed 2019a:11).

Vir Breed is drie siklusse hier van belang. ${ }^{4} \mathrm{Hy}$ gebruik die 'verslawende siklus' om die proses van verslawing (die sondesiklus) te illustreer. Die wet-siklus (waar klem slegs op die wet, oftewel die tien gebooie geplaas word) word deur sommige gebruik in hulle pogings om die verslawing te breek deur konfrontasie daarmee. Die genade-siklus, waar die fokus op die wette sowel as die genade van die Here geplaas word, word deur Breed voorgehou ten einde die verslawing te breek (Breed 2016:10, 2019a:10). Die kern van die genade-siklus is die beginsel dat druk of skuldgevoelens (die wet- en sonde-siklus) nie genesing tot gevolg het nie; genesing kom eerder deur die genade van die Here (die genade-siklus) en op hierdie manier word liefde en dankbaarheid by pastorante gekweek. Liefde en dankbaarheid word dan die dryfveer vir gehoorsaamheid. Dit veroorsaak'n gevoel van vrymoedigheid in pastorante wat hulle in staat stel om herhaaldelik na die Here terug te gaan, selfs wanneer hulle geval het. Sodoende word eensaamheid en onttrekking vermy, en word die siklus van val en terugkeer mettertyd verkort.

In die genade-siklus word rooi vlae (bv. eensaamheid, angs, vrees en gevoelens van waardeloosheid) wat gewoonlik 'n gekondisioneerde reaksie (refleks) veroorsaak, geïdentifiseer

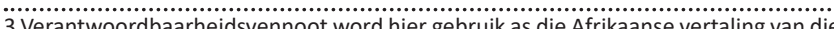
term 'accountability partner' wat verwys na 'n persoon in die lewe van die pastorant wat die pastorant bystaan om getrou te bly tot ' $n$ verbintenis.

4.Die beperkte lengte van die artikel laat nie ruimte om die drie siklusse waarna hier verwys word te bespreek nie. 
en hanteer. Die pastorant word begelei om, in plaas daarvan om voort te gaan in die sonde-siklus of die wet-siklus, bewustelik 'nee' te sê vir die gekondisioneerde refleks, en die nuwe genade-siklus te kies. Dit wat in die Coram Deo-fase ontdek is (valse oortuigings, waarhede, God se genade en die drie ankerpunte) word weereens bevestig. Van hier af neem die pastorant die besluit om weg te stap van hierdie pyn deur 'nee' te sê vir die valse oortuigings en verkeerde optrede, en om hierdie innerlike leemte en leegte te vul met die genade van die Here deur daarvoor 'ja' te sê (Ps 16 en 23). Die gevaar van terugval in ou patrone is ' $n$ werklikheid. Daarom speel verantwoordbaarheidsvennote 'n belangrike rol. Wanneer pastorante bewus word van 'n 'rooi vlag'-situasie, kan hulle hul verantwoordbaarheidsvennote kontak wat hulle pertinent weer aan die gesprek met God herinner wat sal help om hulle leegheid met die wette en die genade van die Here te vul (Breed 2016:12)

Dit is belangrik om enige vorm van verslawing deur sonde voor die Here te bely en weereens te besef dat Hy pastorante op hulle name ken, dat hulle aan Hom behoort en dan sy vergifnis te aanvaar. Van hier af kies pastorante weer om uit die liefde van die Here te lewe.

Pastorante verbind hulle dan opnuut tot die waarhede wat tydens die Coram Deo-fase geleer is, en bevestig en herhaal dat hulle glo dat hierdie waarhede die Woord van die Lewe is. Breed (2016:11) beklemtoon hierdie toewyding en verbintenis tot die waarheid, maar voel dat dit ook belangrik is om die pastorant verder positief te begelei om ook dienswerk te doen (Breed 2019b:10).

Deur selfs net een maal suksesvol deur die hele genadesiklus te beweeg, word hoop gewek.

Pastorante ervaar dan eerstehands hoe volharding hoop skep. Die pastorant sal waarskynlik weer en weer deur hierdie proses gaan en elke nou en dan val, maar die doelwit is om elke keer nie so diep soos die vorige keer te val nie en om altyd terug te keer na die Here wat die oplossing bied vir die leegheid en pyn. Die oogmerk is om pastorante op 'n punt te bring waar hulle nie bloot hul situasie verdra nie, maar eerder om elke keer wanneer hulle deur die genade-siklus gaan, nuwe hoop te ontvang en te ervaar.

\section{Die vierde fase van ondersteuning en opvolg}

Die vierde fase van Breed se model is in wese 'n voortsetting van die vorige fase van gehoorsaamheid en volharding. Die pastorale praktisyn kan nie onbepaald intensief met die pastorant werk nie en dit sou ook nie die volledige plan van God vir die bediening wees nie. Die onus val meer op die gemeenskap van gelowiges waarby die pastorant betrokke is vir voortgesette ondersteuning en geestelike groei (Breed 2016:10; Goode 1994:306).

Breed (2016:12; 2019a:12) baseer hierdie fase op die 'mekaar'tekste in die Bybel wat ' $n$ aanduiding is van die klem wat
God plaas op die rol wat gelowiges in mekaar se lewens het ter ondersteuning van mekaar:

- Jakobus 5:16 lui: 'Bely julle sondes eerlik teenoor mekaar en bid vir mekaar, sodat julle gesond kan word.' Die gebed van 'n gelowige het 'n kragtige uitwerking. Breed (2016:12) beskou dit as die kern van wat 'n kerk behoort te wees. Anders as wat dikwels ervaar word, is 'n gemeenskap van gelowiges nie veronderstel om 'n plek te wees waar mense agter maskers van 'ons is almal oukei' skuil nie. 'n Gemeente is in werklikheid 'n samekoms van sondaars wat juis kerk toe kom omdat hulle weet dat hulle sondaars is en dat almal in die geloofsgemeenskap die Here, die redding van Christus, die genade van God en die krag van die Heilige Gees nodig het. Gelowiges (sondaars) sluit dus aan by 'n geloofsgemeenskap om die genade van God te ontvang en Hom daardeur te loof.

Die gemeenskap van gelowiges moet die omgewing wees waarbinne mense die vertroue kan hê om hulle sondes aan mekaar te bely, om hulp te vra en om voor gebid te word ten einde genesing te vind. In die genade-siklus het pastorante dus ander mense nodig om vir hulle te bid, hulle te vertel van en te herinner aan die genade van die Here en hulle verder te ondersteun en deur hierdie proses te dra:

- Efesiërs 4:32 lui: 'Wees eerder vriendelik met mekaar. Gee vir mekaar om. Vergewe mekaar soos God julle vergewe het op grond van wat Christus gedoen het.' Die gemeenskap van gelowiges is nie bedoel om 'n plek te wees om vinger te wys of waar sonde geïgnoreer word nie. Aangesien gelowiges weet dat sonde afbreek en pyn veroorsaak, wil hulle mekaar help om van sonde weg te breek. Ongeag wie die medegelowiges (sondaars) is of wat hulle omstandighede is, die Here beveel gelowiges om vriendelik en teer teenoor mekaar te wees en mekaar te help en te ondersteun. Nuwelinge in 'n gemeenskap van gelowiges moet warmte en aanvaarding ervaar en 'n gevoel van omhelsing; om nader getrek te word, ongeag wie hulle is, want dit is wat God vir hulle gedoen het (Breed 2019a:12).

- 1 Tessalonisense 5:14: 'Ons druk julle dit op die hart, broers: Wys die leeglêers onder julle tereg, praat die kleinmoediges moed in, help die swakkes, wees met almal geduldig.' Hierdie vers bepaal die houding wat gelowiges teenoor mekaar behoort te hê. Die klem moet nie net op die hantering van sonde en die ondersteuning van die swakkes wees nie, maar ook op die aanmoediging van diegene wat moedeloos is of voel dat hulle nie kan aangaan nie. Hierdie ondersteuning kan nie net die verantwoordelikheid van die predikant en/of pastorale praktisyn wees nie. Daarom is die res van die gemeenskap van gelowiges ook nodig (Breed 2019a:11).

\section{Samevatting}

'n Verkennende, beskrywende perspektief op Breed se verstaan van 'n bybelse model vir die pastoraat is in hierdie artikel aangebied. Die kern van die model is die klem op oortuigings wat ' $n$ bepalende rol speel in die optrede en gespreksvoering van pastorante met hulleself, hulle situasie, 
ander mense en God. Deur pastorante te begelei om in die liefde van God, die versoening van Christus en die troos van die Heilige Gees geanker te wees, word 'n lewe in die aangesig van die Here gekweek. Dit is in hierdie posisie van Coram Deo wat ware genesing en volhoubare vervulling gevind word.

Breed se verstaan van 'n bybelse model tot die pastoraat is by uitstek veral bruikbaar in die opleiding van predikante en beraders in die gereformeerde tradisie vir die pastoraat.

Daar sou gevra kon word hoe toepaslik Breed se model sou wees in pastorale en spirituele sorg waar die pastorale praktisyn in verskeie kontekste toenemend gekonfronteer word met pastorante met 'n eiesoortige geloofsraamwerk wat moontlik verskil van dié van die pastorale praktisyn.

'n Oorvereenvoudige verstaan of oorbeklemtoning van elemente van die model (bv die vertikale dimensie) sou, soos Breed duidelik waarsku, risiko's inhou wat na my mening, etiese waardes soos daargestel deur professionele liggame, byvoorbeeld die Council for Pastoral and Spiritual Counsellors (CPSC) in gedrang kan laat kom. Dit sluit respek, beste belang of welstand, menseregte, outonomie, integriteit, verdraagsaamheid en deernis in (CPSC 2021:1).

My evaluering van Breed se model is egter dat dit wel veel wyer in die hedendaagse konteks toepaslik is. Hierdie siening is gegrond op Breed se beklemtoning van Coram Deo wat sentreer rondom die beginsel dat die pastorale praktisyn juis vanuit die posisie van ' $n$ begenadigde mens, met warmte en aanvaarding die pastorant as 't ware vergesel en begelei op sy of haar reis om in die teenwoordigheid van en vertroue in die Here te leef. Die pastorale praktisyn help verder om pastorante se lewens in die teenwoordigheid van God in oënskou te neem en toenemend te groei in kennis, begrip, dankbaarheid en ervaring van die liefde van God die Vader, die versoening van die Seun en die troos van die Heilige Gees.

\section{Erkenning}

Baie dankie aan Prof. Gert Breed vir toestemming om oor sy werk na te vors en te skryf.

\section{Mededingende belange}

Die outeur verklaar dat daar geen finansiële of persoonlike verbintenis is met enige party wat haar nadelig kon beïnvloed in die skryf van hierdie artikel nie.

\section{Outersbydrae}

R.P. was die enigste outeur betrokke by die skryf van die artikel.

\section{Etiese oorwegings}

Hierdie artikel volg alle etiese standaarde vir navorsing.

\section{Befondsing}

Hierdie navorsing het geen spesifieke toekenning ontvang van enige befondsingsagentskap in die openbare, kommersiële of niewinsgewende sektore.

\section{Databeskikbaarheid}

Die outeur bevestig dat die data wat die bevindinge van hierdie studie ondersteun, beskikbaar is in die artikel.

\section{Vrywaring}

Die sienings en menings wat in hierdie artikel uitgedruk word, is dié van die outeur en weerspieël nie noodwendig die amptelike beleid of posisie van enige geaffilieerde verwantskap van die outeur nie.

\section{Literatuurverwysings}

Breed, G., 2013b, 'Metateoretiese vertrekpunte ten opsigte van wetenskaplike navorsing in die pastorale wetenskap', In die Skriflig/In Luce Verbi 47(1), 1-8. https://doi.org/10.4102/ids.v47i1.96

Breed, G., 2016, 'n Bybelse pastorale model, lesings 1-12, verkry uit PAST121 NWU, Potchefstroom. (Ongepubliseer).

Breed, G., 2019a, Pastorale studies: Bybelse berading, lesings 1-12, verkry uit PAST122 NWU, Potchefstroom. (Ongepubliseer).

Breed, G., 2019b, Living as a diakonos of Christ and pastoral care to the narcissistically entitled person, viewed 13 April 2021, from https://www.semanticscholar.org/ paper/Living-as-a-diakonos-of-Christ-and-pastoral-care-to-Breed/45608c9e78ab paper/Living-as-a-diakonos-of-Christ-

Council for Pastoral and spiritual counsellors (CPSC), 2021, CPSC ethical values and standards, viewed 14 April 2021, from https://www.cpsc.org.za/affiliation/ documents.

Crabb, L.J., 1978, Effective Biblical counseling, Zondervan, Grand Rapids, MI.

Goode, W.W., 1994, 'Biblical counseling and the local church', in J.F. MacArthur \& W.A. Mack (eds.), Introduction to Biblical Counseling: A basic guide to the principles and practice of counseling, pp. 301-310, Word Incorporated, Dallas, TX.

MacArthur, J.F., 1994, 'Spirit-giftedness and biblical counseling', in J.F. MacArthur \& W.A. Mack (eds.), Introduction to biblical counseling: A basic guide to the principles and practice of counseling, pp. 131-141, Word Incorporated, Dallas, TA.

Osmer, R.R., 2008, Practical theology: An introduction, Wm. B. Eerdmans Publishing, Grand Rapids, MI.

Pretorius, R., 2017, 'Pastoral care and counselling of families with deaf children: A practical theological model', PhD thesis, North-West University, 